\title{
Menelaah Pembagian Profesi Catur Warna ditinjau dari Implementasi Ajaran Catur Asrama
}

Oleh:

Tardi Edung

\begin{abstract}
Perubahan sosial pasti terjadi dan hal ini berlangsung selama masih ada kehidupan di muka bumi ini. Peningkatan status sosial individupun dalam masyarakat terjadi sesuai dengan profesi yang ditekuni, perubahan dan peningkatan kedudukan seseorang mutlak adanya. Bagaimanakah status sosial individu dilihat dari ajaran catur asrama. Problematik hidup cukup beragam dan komplek mengharuska individu hidup diatur oleh peraturan, norma dan kaidah yang ada dalam masyarakat tersebut dan tidak satupun yang boleh mengingkarinya.

Kasta adalah profesi seseorang dalam masyarakat yang membentuk diri dalam kelompok, susunan yang alami. Warna/kasta menggambarkan semangat karakteristik yang sintesis dalam pikiran Hindu dengan keyakinan terhadap kolaborasi dari ras dan kooperasi dari budaya, sistem kasta adalah hasil dari toleransi dan kepercayaan. Disisi lain warna/kasta secara rasial merupakan penekanan dari perbedaan yang pasti dalam kelompok manusia yang tidak mungkin dapat dihapus atau dimusnahkan oleh perubahan sosial. Ajaran ini menentukan terhormat atau tidaknya seorang individu dalam kedudukannya di masyarakat yang homogen dan multikultur yang berlandaskan nilai-nilai dan norma-norma sebagai aturan hidup. Peralihan status sosial individu disesuaikan dengan profesi yang ditekuni dalam masyarakat baik diperoleh berdasarkan ilmu pengetahuan, penghargaan berupa kehormatan dan kekuasaan. Perubahan profesi dapat terjadi karena ilmu pengetahuan, pendewasaan berumah tangga, intropeksi diri dan menanggalkan semua kedudukan di dunia ini ke tahapan yang lebih komplek. Catur asrama memberi arah kedudukan individu dalam masyarakat.
\end{abstract}

Kata Kunci : Catur karna/kasta, catur asrma, sosial masyarakat.

\section{Pendahuluan}

\section{Latar Belakang}

Rakyat merupakan keseluruhan penduduk suatu wilayah tertentu atau suatu daerah tertentu yang berdaulat, yang menerima konstitusi maka setiap orang/manusia praktis memiliki hak dan kewajiban yang dijalankan. Rakyat hidup di dalam masyarakat berbaur dengan sejumlah manusia dalam kurun waktu cukup lama sehingga melahirkan budaya dengan satu kesatuan kriteria dalam memiliki sistem hidup bersama. Selanjutnya sistem ini menjadi hubungan kekerabatan, pergaulan, kerja, pemerintahan, hunungan formal dan in formal, keturunan dan sebagainya. Manusia dalam proses 
kehidupan di masyarakat hidup berdasarkan karakternya masingmasing dan selalu berusaha untuk memperbaiki kualitas dirinya sendiri, karena tidak mungkin diri sendiri bisa berubah tanpa usaha sendiri. Kehidupan sosial akan berubah diiringi oleh peningkatan peran dan kedudukan dalam masyarakat dalam arti luas, hal ini akan diperoleh apabila diri sendiri memiliki kemampuan dan pengetahuan hal ini tentu sejalan dengan Harapan bangsa Indonesia di tahun 2045 nanti menjadi generasi emas yaitu generasi yang memiliki IQ, karakter muliadan berbudaya untuk dapat membangun peradaban baru yang sesuai dengan karakteristik bangsa patut di maknai secara positif dan diupayakan sebagai suatu cita-cita yang mulia. Searah dengan upaya untuk mengembangkan potensi diri dalam masyarakat menurut Syarbaini dan Rusdiyanta (2009) "kajian tentang masyarakat dan tentang kehidupan sosial". Dilihat dari kacamata sosiologi terhadap fakta sosial, tindakan sosial, khayalan sosial dan realitas sosial.

Masyarakat umat Hindu adalah sekelompok manusia yang memiliki kriteria sama dalam mencapai tujuan yang dicita-citakan yang terbagi atau tersusun atas warna untuk membedakan profesi masing-masing. Warna atau kasta ini memperjelaskan peran dan kedudukan seseorang dalam masyarakat umat Hindu, bagi sebagian masyarakat umat Hindu masalah warna/kasta ini tidak bermasalah tetapi di sisi lain banyak yang mempertanyakannya. Bilamana kasta/warna ini tumbuh dan dilaksanakan dalam masyarakat maka seyogyanya mejadi masalah masalah sosial tentu dapat dilihat dan dipahami serta dimaknai keberadaannya dalam kajian sosial. Selanjutnya bila dilihat dari kaliyuga bahwa hidup bukanlah penantian tetapi hidup adalah perjuangan dan memotivasi diri untuk dapat melepaskan diri dari hidup yang memang dalam kelahiran adalah sengsara. Atau menurut Mertha (2009) adalah "manusia sebenarnya menyadari betapa dalam setiap sistem dan sub sistem kehidupan adalah menderita, tetapi kelahiran sudah dibekali budhi dan manah dengan didominasi oleh kekuatan moral, maka manusia seharusnya dapat mengatasi sendiri penderitaannya tersebut". Berdasarkan penjelasan ini maka semakin jelas bahwa individu khususnya umat Hindu dalam 
menyikapi warna/kasta melalui kemampuan akal budi yang sudah ada.

Peran dan kedudukan seseorang dalam masyarakat umat Hindu ditentukan oleh warna/ kasta yang dimiliki, hal semacam ini seolah telah menjadi suatu yang membudaya di kalangan umat Hindu sendiri. Pandangan semacam ini tidaklah sepenuhnya benar apabila dikaji melalui ajaran catur asrama, bahwa tingkat atau tahapan hidup manusia juga dapat meentukan warna/kasta seseorang. Karakter seseorang juga memegang peran penting untuk menentukan status sosial seseorang dalam masyarakat, status sosial ini selanjutnya akan memperlihatkan warna seseorang. Menurut pandangan Hindu bahwa modernisasi bukanlah situasi yang semuanya serba wah serba cemerlang dan glamor, khususnya apabila diapresiasikan ke dunia theistis (cettana) spirit keagamaan. Bergesernya pola hidup dan kedudukan manusia sah-sah saja sebab apabila hidup ini tidak disinergikan dengan situasi yang sedang berlangsung, maka manusia akan tertinggal jauh bahkan akan menjadi manusia ekslusif, tersisih dari hidup dalam percaturan masyarakat. Kekayaan ajaran Agama Hindu yang juga bersifat universal memberikan kebebasan kepada umatnya untuk memberikan ulasan sesuai dengan kemampuan masingmasing. Tulisan ini menganalisa melalui pemahaman ajaran catur asrama mengenai bagaimanakah status sosial kemasyarakatan seseorang secara individu maupun kelompok berdasarkan catur warna/kasta.

\section{Tujuan}

Secara umum tujuan yang dicapai dari pembahasan ini adalah untuk memahami kehidupan sosial dalam masyarakat yang perlu ditingkatkan kualitas dan kemampuan, sekaligus memberikan gambaran secara transparan bahwa tantangan yang dihadapi semakin berat maka kualiats sumber daya manusia perlu ditingkatkan berdasarkan jenjang atau tahapan hidup dalam masyarakat.

\section{B. Pembahasan}

\section{Individu atau Kelompok}

\section{Manusia Dalam Masyarakat}

Manusia dalam menjalankan kehidupan bersama di masyarakat dihadapkan pada problematik hidup yang cukup beragam hal ini dapat dilihat dari tingkat yang terkecil sampai pada tingkat yang besar dan complek. 
Setiap individu atau kelompok yang hidup di masyarakat diatur oleh peraturan, norma dan kaidah yang ada dalam masyarakat tersebut dan tidak satupun yang boleh mengingkarinya. Selanjutnya dalam hidup bersama tersebut individu atau kelompok berada pada status sosialnya masingmasing mejadi peran yang wajib dimainkan, pencetusan status sosial atau peran ini tentu diperoleh oleh masing-masing baik oleh faktor keturunan maupun oleh hasil pendidikan dann pengajaran. Dengan demikian maka layak atau pantas individu tersebut menyandangnya sebagai suatu peranan, dalam kehidupan yang lebih complek status sosial ini kecendrungan banyak dan beragama tetapi dalam kehidupan yang kecil dan bersahaja peran ini cukup sedikit.

Kehidupan sosial dalam masyarakat yang diatur dan dituntun berdasarkan norma-norma sosial serta peraturan, walaupun dalam prakteknya tidak selamanya sesuai dengan normanorma dan peraturan yang ada. Ini berarti bahwa dalam kehidupan di masyarakat tidak semuanya dapat berjalan dengan lancar dan normal sesuai dengan kehendak dalam masyarakat bersangkutan. Setidaknya ada dua macam persoalan yang sering terjadi yaitu problem masyarakat dan problem sosial, di mana problem masyarakat akan berbicara analisia mengenai macam-macam gejala kehidupan bermasyarakat sekaligus berbicara mengenai gejala abnormal dalam masyarakat /kajian yang dilakukan apakah untuk memperbaikinya atau berusaha untuk menghilangkannya. Selanjutnya problem sosial adalah ketidaksesuaian antara unsur-unsur dalam kebudayaan atau masyarakat bahkan dapat menghambat kehidupan kelompok sosial dan keinginan warga kelompok sosial. Kedua problema sosial ini dalam masyarakat perlu mendapat perhatian serius selanjutnya juga perlu pengkajian yang mendalam terhadap obyek yang ada dalam masyarakat.

Kelompok sosial menurut Syarbaini dan Rusdiyanta (2009) adalah "kesatuan sosial yang terdiri dari kumpulan individu yang hidup bersama dengan mengadakan hubungan timbal balik yang cukup intensif dan teratur, sehingga diharapkan adanya pembagian tugas, struktur serta norma-norma tertentu yang berlaku". Kelompok sosial ini 
menjadi penting sebab setiap aktivitas manusia dapat dipastikan berlangsung di dalamnya, disadari atau tidak disadari bahwa manusia sejak di lahirkan sudah masuk menjadi anggota dalam kelompok sosial yang sudah ada. Atau dengan kata lain pelapisan sosial sebenarnya mulai ada sejak masyarakat tersebut mengenal kehidupan bersama yakni dari masyarakat yang sederhana sampai kepada masyarakat modern. Artinya bahwa kehidupan sosial dalam masyarakat sesungguhnya merupakan hubungan sosial yang terjadi di masyarakat, bahkan terjadinya pelapisan sudah ada sejak kehidupan ini ada dalam melakukan hubungan.

Pengetahuan dan pemahaman terhadap harkat dan martabat manusia tercermin dalam tingkat pendidikan serta wawasan pengetahuan, profesi yang ditekuni sebagai bidang pekerjaan, peran dan kedudukan dalam hidup sosial masyarakat, sradha dan bhakti serta kemampuan hidup dalam keberagaman. Artinya bahwa manusia akan berusaha untuk memanusiakan dirinya sendiri atau manusia akan berusaha meningkatkan kemanusiaannya sendiri. Menurut Karda dkk (2007) bahwa dalam kemasyarakatan atau sosiologi Hindu peran umat dalam mewujudkan kesejateraan (madani), dan tanggung jawab umat dalam mewujudkan hakhak azasi manusia menjadi hal penting. Kehidupan sosial di masyarakat menurut pandangan agama Hindu berdasarkan pelapisan dan diperankan oleh individu atau kelompok berdasarkan profesinya masing-masing sekaligus ditekuni sebagai pekerjaan sehingga dapat menentukan status sosial seseorang.

Tentu saja di tengah globalisasi dan era kompetisi dewasa ini generasi yang berkarakter tidak bisa diabaikan, pemahaman terhadap nilai-nilai karakter bangsa mutlak dipahami dan dikembangkan. Budaya kerja yang menjadi acuan seperti integritas, profesional, inovatif, tanggung jawab dan ketauladanan senantiasa memberikan roh dan kekuatan kepada masyarakat dengan kata lain mampu melaksanakan tugas dan fungsinya masing-masing agar mencapai tujuan bersama. Sejalan dengan hal tersebut ajaran agama Hindu mengenai catur warna/kasta dengan jelas telah membagikan profesi seseorang berdasarkan jenjang pengetahuan dan pemahaman yang dimiliki. Empat warna ini adalah profesi yang 
dijalankan di tengah kehidupan masyarakat secara umum maupun secara khusus dalam lingkungan masyarakat Hindu. Setiap individu atau kelompok senantiasa mempunyai penghargaan tertentu terhadap hal-hal tertentu yang ada dalam masyarakat bersangkutan, dan hal ini merupakan dapat menjadi pelapisan dalam masyarakat. Sejalan dengan Sorokin yang menjelaskan bahwa sistem lapisan merupakan ciri yang tetap dan umum dalam setiap masyarakat yang hidup tereatur.

\section{Pengertian Catur Warna}

\section{Benarkah}

kasta/warna

merupakan tingkatan tinggi rendahnya status sosial dan profesi seseorang dalam masyarakat ? apakah kasta diturunkan secara turun temurun berdasarkan garis keturunan? selanjutnya masih dibingungkan dengan adanya profesi yang tidak mungkin dapat digantikan oleh orang lain dan sederet pertanyaanpertanyaan baik secara etika maupun filsafat terhadap kasta/warna ini. Menurut Joseph Schumpeter seperti dijelaskan oleh Soekanto (2009) bahwa kelas-kelas dalam masyarakat terbentuk karena diperlukan untuk menyesuaikan masyarakat dengan keperluan-keperluan nyata, kelas dan gejala kemasyarakatan hanya dapat dipahami apabila ketahui riwayat terjadinya. Istilah kelas ini pada hakekatnya akan mewujudkan sistim kedudukan yang pokok dalam masyarakat. Suatu kelompok sosial biasanya cendrung untuk tidak menjadi kelompok yang statis akan tetapi selalu berkembang dan mengalami perubahan-perubahan baik dalam aktivitas maupun bentuknya. Kelompok ini diharapkan dapat menambah sarana perlengkapan guna melaksanakan fungsi-fungsi baru dalam rangka perubahan-perubahan yang dialami bahkan sebaliknya akan dapat mempersempit ruang lingkup.

Tantagan yang dihadapi semakin berat kompetisi memerlukan kemmapuan daya saing yang tidak saja hadirnya dinamika perkembangan ilmu pengetahuan tetapi juga disebabkan oleh market yang dihasilkan. Dewasa ini ruang lingkup tantangan tidak terbatas pada lingkungan masyarakat saja tetapi lebih luas jangkauannya seperti negara, disinilah awal dari sebuah proses kehidupan dengan tantangan yang lebih dinamis dan kompleks. Sedangkan pada masyarakat-masyarakat yang kecil 
serta bersahaja biasanya kedudukan dan peran bersifat sangat minim

Karda dkk (2007) berpendapat bahwa materi sosialogi Agama Hindu secara garis besar terbagi atas dua bagian yakni, keluarga dan masyarakat serta catur warna yang dikaitkan dengan profesi masing-masing individu. Pendapat ini sejalan dengan pandagan Parsons yang menyatakan bahwa " kebebasan untuk melakukan sebuah tindakan tatap ada pada setiap individu yang hidup bermasyarakat, tetapi kebebasan tersebut di batasi oleh standar-standar normatif yang berlaku dalam kehidupan masyarakat”.

Sistem kasta/warna ini sudah ada sejak berabad-abad silam yang terdiri dari Brahmana, Ksatria, Waisa dan Sudra. Susunan kasta/warna ini cukup komplek bahkan hingga sekarang ini masih tetap dipertahankan, keempat kasta atau warna ini merupakan lapisan dalam masyarakat yang menggologkan individu atau kelompok. Brahmana merupakan lapisan tertinggi sebagai pendeta dalam masyarakat, Ksatria merupakan lapisan orang-orang bangsawan, Waisa adalah para pedagang yang memegang perekonomian dalam masyarakat dan
Sudra merupakan lapisan terendah dianggap sebagai rakyat jelata atau rakyat biasa yang memiliki keahlian dan kemampuan sebagai buruh atau petani. Sementara di sisi lain kedudukan dan peran meruapakan unsur-unsur baku dalam sistem lapisan sekaligus memiliki arti penting dalam sistem sosial yang mengatur hubungan timbal balik antar individu dalam masyarakat, sekaligus berguna untuk mengatur keseimbangan.

Richards (2004) meyetir pendapat tokoh pembaharu Hindu Dayananda Saraswati "Saya merasa bahwa warna (kasta atau kelas atau susunan individu) ditentukan oleh perbuatannya (kualifikasi) dan tindakannya". Pendapat ini sesungguhnya ingin meletakan warna sesuai dengan kualifikasinya, prestasi dan karakter. Berdasarkan pendapat di atas bahwa untuk dapat meningkatkan kualitas dan kemajuan sangat penting menguasai ilmu pengetahuan dan budaya. Sedangkan Vivekananda berpendapat "kasta adalah sebuah karakter dari masyarakat yang membentuk diri dalam kelompok, susunan yang alami”. Artinya bahwa manusia harus membentuk diri dalam bentuk kelompok dan kasta itu tidak 
bisa dihilangkan walaupun untuk kepentingan reformasi sosial. Radhakrishnan menyatakan bahwa "Institusi Warna/kasta menggambarkan semangat karakteristik yang sintesis dalam pikiran Hindu dengan keyakinan terhadap kolaborasi dari ras dan kooperasi dari budaya, sistem kasta adalah hasil dari toleransi dan kepercayaan. Disisi lain warna/kasta secara rasial merupakan penekanan dari perbedaan yang pasti dalam kelompok manusia". Hal ini disebabkan oleh sampai saat ini penggolongan seseorang berdasarkan kasta/warna masih saja terjadi walaupun dalam volume yang terbatas. Kasta/warna dalam ajaran agama Hindu yang sudah ada sejak berabad-abad tidak mungkin dapat dihapus atau dimusnahkan oleh perubahan sosial.

\section{Pengertian Catur Asrama}

Hidup dan kehidupan manusia secara hedonisme merupakan hidup yang menginginkan kenikmatan dan kegembiraan/kebahagian. Sementara dari sisi lain berdasarkan sastra agama bahwa kelahiran menjadi manusia ke dunia ini adalah penderitaan atau kesengsaraan. Karakter manusia tidak menginginkan hidup sengsara, miskin, sedih dan duka meskipun dikatakan bahwa hidup dan lahir sebagai manusia adalah satu kosmos (mahluk) yang paling tinggi dan sempurna. Menurut Mertha (2009) bahwa "motivasi hidup menggunakan jasa hedonisme keberhasilan sangat ditentukan oleh kemampuan manusia dalam perjuangannya menundukkan rajastamas". Menjadi tugas dan kewajiban manusia untuk selalu berusaha dalam kancah percaturan hidup kearah yang lebih baik, manusia harus menyadari bahwa manusia tidak hidup sendirian tetapi manusia adalah bagian dari satu kehidupan kelompok manusia yang disebut dengan masyarakat. Kehidupan manusia yang komplek mengharuskan manusia berjuang dan tampil sebagai individu yang utuh penuh dengan semangat untuk berubah dan berubah.

Tuhan telah memberikan manusia akal dan pengetahuan untuk hidup dan kehidupan, sebab dengan akal dan pengetahuan itu dia (manusia) akan dapat merekayasa hidupnya untuk kebahagiaan diri sendiri dan orang lain. Walaupun dewasa ini telah terjadi pergeseran cara hidup, dari hidup komunalitas bergeser ke individual, hidup mendukung etika dan moralitas bergeser ke hidup konsumtif 
dan individualistik materialistik. Secara bersama-sama dalam kelompok masyarakat terutama umat Hindu mari membuka cakrawala baru dengan menguatkan kosep-konsep keHinduan dalam kehidupan, bangkit menjadi generasi yang cerdas, tangga, peduli dan bertanggungjawab terhadap dinamika sosial masyarakat sekaligus menjunjung nilai-nilai Pancasila yang sudah mengakar dalam rasa dan logika, generasi yang bermartabat.

Salah satu dinamika kehidupan sosial yang perlu dibahas adalah stratafikasi sosial yang ada dalam masyarakat, stratafiaksi ini merujuk kepada kedudukan sosial seseorang dalam kehidupan masyarakat. Menurut Syarbaini dan Rusdiyanta (2009) stratafikasi sosial "muncul akibat ada gejala di mana masyarakat mempunyai penghargaan tertentu terhadap hal tertentu dalam masyarakat bersangkutan, yakni pembedaan posisi seseorang atau suatu kelompok dalam kedudukan yang berbeda-beda secara vertikal". Penghargaan yang dimaksud dapat berupa kekayaan, ilmu pengetahuan, status kebangsawanan, dan kekuasaan. Setidaknya ada empat poin penting yang menjadi ukuran atau kriteria yang bisa dipakai untuk menggolongkan individu-individu ke dalam suatu lapisan strata sosial yakni : 1) kekayaan, 2) kekuasaan, 3) kehormatan dan 4) ilmu pengetahuan. Empat point ini wajib diperoleh melalui tahapan atau tingkat hidup dengan menjunjung nilai-nilai dan normanorma.

Ajaran agama Hindu sangat jelas mengajarkan bahwa seseorang untuk dapat dan memperoleh status sosial perlu melalui tahapan atau proses yang di sebut dengan catur asrama yakni melaksanakan masa brahmacarya, masa grehasta, masa wanaprasta dan masa sanyasin/biksuka asrama. Keempat tahapan atau jenjang kehidupan ini menurut ajaran agama Hindu wajib dilewati sekaligus dilaksanakan oleh individu umat Hindu, karena individu hidup bersama dalam lingkungan masyarakat baik secara intern maupun secara ekstern. Status sosial yang diperankan dalam kehidupan masyarakat terkait dengan catur kasta/warna akan dijelaskan melalui pemahaman ajaran catur asrama, di mana ajaran ini akan ikut menentukan terhormat atau tidaknya seorang individu dalam kedudukannya di masyarakat yang homogen dan multikultur yang berlandaskan nilai- 
nilai dan norma-norma sebagai aturan hidup.

Pertama individu memasuki masa brahmacari asrama, yakni di mana seseorang wajib untuk mengikuti dan menjalankan masa untuk menuntut ilmu pengetahuan. Masa ini ditandai dengan proses pelaksanaan pendidikan dan pengajaran pada setiap jenjang atau tingkat pendidikan sehingga individu wajib untuk konsentrasi penuh terhadap materi yang diajarkan oleh seorang Acarya (guru pengajian). Pelaksanaan proses pendidikan dan pengajaran ini akan memberikan kontribusi terhadap individu untuk mengubah serta meningkatkan status sosial dalam masyarakat sesuai dengan profesi yang ditekuninya. Ilmu pengetahuan memberikan andil cukup besar untuk mengubah pola atau aturan yang ada dalam masyarakat, orang/individu yang memiliki ilmu pengetahuan akan disegani dan dihormati berdasarkan kemampuan dan keahliannya. Pentingnya menguasai ilmu pengetahuan dan teknologi bagi individu akan dapat mengubah cara pandang dan pola hidup seseorang dalam masyarakat dan dengan mudah untuk memperoleh status sosial pada level yang di hormati dan disegani. Artinya dengan menguasai ilmu pengetahuan individu akan mengubah hidup dan kehidupannya kearah yang lebih baik dari sebelumnya dan menggunakan ilmu pegetahuaan tersebut sesuai dengan fungsi dan kegunaanya.

Artinya bahwa pada tahap ini individu hanya fokus untuk memperoleh dan mendalami ilmu pengetahuan, kegunaan ilmu pegetahuan secara luas dapat dipahami sebagai suatu kebutuhan mendasar untuk melakukan perubahan. Secara implisit dapat dianalogkan bahwa dengan menguasai ilmu pengetahuan profesi individu dapat ditentukan sebagai contoh ketika belum mendapat pendidikan individu tergolong pada kasta atau warna sudra tetapi ketika berpendidikan bisa saja kasta ini berubah menjadi pendeta, ksatria, atau menjadi seorang ekonom. Peluag perubahan dan peningkatan status sosial seperti ini lebih banyak menekankan pada kemampuan kualitas sumber daya manusia yang dimiliki oleh individu yang didapat melalui proses pendidikan dan pengajaran di bawah bimbingan seorang guru. Ini artiya bahwa ilmu pengetahuan salah 
satu sumber terjadinya perubahan status dalam masyarakat.

Kedua individu memasuki masa grehasta asrama, artinya bahwa seseorang akan meninggalkan masa lajangnya dan menyatukan dua karakteristik yang berbeda untuk membina kehidupan berumah tangga dan untuk melahirkan seorang saputra yang akan meneruskan dan melangsungkan kehidupan leluhurnya. Masa grehasta asrama ini juga akan dapat menentukan status sosial individu di tengah-tengah masyarakat, hal ini biasanya orang akan memandang dari keharmonisan kehidupan keluarga yang dibina, keberhasilan dalam menjalani hidup, keberhasilan dalam membina putra putri, hubungan dengan masyarakat dan keluarga dan masih banyak lagi keberhasilan. Sehingga dengan sendirinya menjadi individu yang dihormati dan disegani dalam masyarakat dengan demikian juga akan merubah kedudukan dan peran individu tersebut.

Masa grehasta asrama di mana individu sudah menetapkan hidup bermasyarakat dengan keluarga, kedudukan dalam masyarakat akan dapat berubah bila individu memiliki kemampuan dan skill yang dapat diberikan kepada masyarakat dan berguna bagi semua lapisan. Kaitannya dengan catur warna/kasta adalah ketika individu dalam masa grehasta ini diberikan penghargaan atau kepercayaan sesuai dengan profesi sehingga menjadi terpandang dan dihormati masyarakat. Sebagai contoh riil dapat saja menjadi seorang pedagang yang melayani kebutuhan masyarakat sekitarnya atau menjadi seorang guru baik formal maupun non formal sesuai dengan disiplin keilmuan yang diperoleh individu bersangkuatan. Artinya bahwa perubahan status sosial seseorang individu sangat ketergantungan dengan individu bersangkutan dalam melihat peluang yang ada. Peluag merupakan kesempatan bagi individu berkembang dalam masyarakat terutama bagi para grehasta untuk mengembangkan kemampuannya.

Ketiga yakni masa wanaprastha asrama seseorang atau individu mulai meninggalkan keberadaannya dalam hiruk pikuk kehidupan duniawi ini. Masa ini ditandai dengan perkembangan usia di mana kedudukan dalam masyarakat tidak lagi menjadi tujuan utama yang harus diperjuangkan 
atau dikejar, tetapi masa ini individu berusaha untuk menenangkan dan intropeksi diri serta mengenang perbuatan yang sudah dilakukan. Status individu dalam masa wanaprastha ini sesungguh sudah berubah dan menigkat ke level yang lebih tinggi dari pada tingkat sebelumnya yang masih terikat oleh hukum alam. Kedudukan individu pada masa ini jauh lebih terhormat dari sebelumnya yakni kedudukan yang bersahaja untuk meningkatkan kesadaran hidup sebagai manusia yang tidak sempurna untuk memperoleh kesempurnaan hidup. Sehingga kedudukan dan peranan yang dimainkan jauh lebih berat dan komplek yakni upaya untuk menata sekaligus mengatur irama kehidupan, agar sedikit demi sedikit dapat dilepaskan dan hidup yang dijalankan hanya terfokus pada usaha pelepasan kehidupan duniawi.

$$
\text { Tahapan }
$$

wanaprasta merupakan tahapan paling sulit karena individu berjuang untuk melakukan intropeksi diri dan perlahan-lahan mulai meninggalkan kehidupan duniawi ini menuju kearah kehidupan rohani yang mapan. Tahapan ini menjadi sebuah harapan dan kenyataan bagi individu karena status sosial dalam masyarakat masih melekat. Kaitannya dengan catur kasta/warna adalah bahwa kedudukan sosial individu pada tahapan ini meningkat kearah level yang lebih tinggi yakni menguasai diri terhadap aspek-aspek duniawi terutama menyangkut harta benda, kekayaan, jabatan, kedudukan, kekuasaan dan wewenang dalam masyarakat. Sebagai contoh pada tahapan ini dapat saja individu menjadi seorang guru spiritual, seorang pendeta yang hanya mengajarkan kebaikan dan kebenaran hidup atau melepas sama sekali setiap masalah yang berbau duniawi, karena hal tersebut sudah tidak dibutuhkan lagi oleh individu bersangkutan.

Keempat masa biksuka atau sanyasin asrama adalah individu mengasingkan diri dari kehidupan yang penuh dengan hiruk pikuk duniawi, di mana semua level dan predikat yang diberikan kepada seseorang/individu di tanggalkan. Kehidupan ini lebih sulit dan komplek dari beberapa tahapan atau jejang kehidupan sebelumnya, di mana masa ini individu terbebas dari segala macam bentuk keinginan dan kehendak terutama yang bersifat duniawi. Kedudukan semacam ini lebih kepada kedudukan atau status individu 
sebagai seorang maha guru yang memimpin kehidupan ini dan mengajarkan kepada umat manusia bahwa tahapan ini wajib dikejar oleh setiap individu. Walaupun untuk mencapai tingkatan atau tahapan ini tidaklah mudah bagi individu tetapi melalui usaha yang sungguh-sungguh perubahan status sosial individu ke level yang lebih tinggi akan dapat terwujud dan terealisasi dalam kehidupan.

Tahapan akhir dari catur asrama adalah memasuki masa sanyasin/biksuka pada tahapan ini individu sudah tidak terikat oleh perasaan suka dan duka duniawi dan hanya menjalani kehidupan rohani. Individu semacam ini menanggalkan semua status sosialnya dalam masyarakat dan tidak mengharapkan apapun lagi semua energi difokuskan pada kemanunggalan dengan Sang Pencipta. Kaitannya dengan ajaran catur kasta/warna adalah individu semacam ini sudah memiliki kedudukan sosial yang jauh lebih tinggi dan mulia di bandingkan dengan kedudukan atau status sosial dalam masyarakat. Individu yang sudah menjadi pendeta, menjadi ksatria, menjadi ekonom dan telah menjadi seorang petani atau pelayan dalam masyarakat kini menjadi maha guru bagi sekalian alam semesta. Kehidupan yang maha sulit untuk dicapai atau diraih oleh individu yang masih terikat oleh hukum duniawi, kelas sosial yang paling sempurna dari semua lapisan kelas sosial, posisi paling sempurna di antara posisi yang ada dalam masyarakat.

Kelas sosial di masyarakat lahir sebagai akibat dari adanya pembagian terhadap berbagai jenis pekerjaan, orang-orang yang memiliki status sosial. Posisi-posisi dalam stratafikasi ini dapat dipastikan oleh perbedaan fungsi dan kekuasaan, setiap kelas sosial merupakan substruktur yang terdiri dari sikap, kepercayaan, nilai, norma serta prilaku. Selanjutnya keanggotaan masing-masing kelompok sosial tersebut akan memberikan kedudukan atau prestise tertentu tentunya yang sesuai dengan adat istiadat dan lembaga kemasyarakatan yang ada dalam masyarakat. Sedangkan individu-individu menjadi anggota dari kelompok sosial tertentu berdasarkan keahlian dan kemampuan yang dimiliki dalam memahami gejala kolektivitas. Secara teoretis bahwa semua manusia adalah sederajat namun sesuai dengan 
kenyataan hidup, tidaklah demikian, karena sesungguhnya lapisan sosial dalam masyarakat merupakan gejala universal sekaligus merupakan bagian dari sistem sosial dalam masyarakat terhadap proses-proses dalam lapisan masyarakat.

Penyesuaian individu terhadap perubahan guna mendapatkan keserasian dan keharmonisan dalam masyarakat dan secara psikologis individu merasakan ketentraman karena tidak adanya pertentanganpertentangan yang berlawanan dengan norma-norma dan nilai-nilai yang ada dalam masyarakat. Disinilah letak pentingnya pengetahuan dan pemahaman setiap individu untuk mempelajari perubahan dan mengetahui kemana arah perubahan dalam masyarakat, termasuk perubahan status sosial seseorang dalam kehidupan terhadap kedudukan dan peran yang dimainkan. Perubahan ini terjadi akibat dari proses yang dilakoni oleh individu terhadap kekayaaan, kekuasaan, kehormatan maupun pendidikan, dengan demikian empat poin/aspek ini akan turut menentukan kedudukan sosial seseorang dalam masyarakat. Sebagai contoh kasta/warna Sudra karena kegigihannya dalam menjalankan masa Brahmacarya asrama kedudukannya dapat saja berubah menjadi Ksatria atau Waisya dan sebaliknya. Hal ini tentu di sesuaikan dengan profesi yang ditekuni oleh individu dalam masyarakat.

Setiap individu atau masyarakat pasti mengalami perubahan baik samar, mencolok, lambat, cepat, sebagian/terbatas atau menyeluruh. Perubahan dapat terjadi terhadap individu melalui usaha dan upaya yang dilakukan secara kontinyu dan berkesinambungan. Atau dengan kata lain perubahan terjadi akibat faktor dinamika manusianya yang kreaktif dan aktif, perubahan seperti ini wajib melibatkan semua asfek kehidupan. Peralihan status seseorang ke dalam salah satu kelompok lapisan sosial dalam masyarakat disebabkan oleh meningkatnya pendidikan, prestasi dan kemampuan yang dimiliki oleh individu dalam masyarakat. Mau tidak mau suka tidak suka sistem stratafikasi sosial dalam masyarakat sangat diperlukan guna memahami gejala dan memecahkan persoalan yag dihadapi masyarakat. Sesuai dengan mekanisme yakni dengan menempatkan individuindividu sesuai dengan ketersediaan 
dalam struktur sosial untuk ada dalam masyarakat tersebut dan melaksanakan kewajiban sejalan tidak satupun yang boleh dengan kedudukan dan fungsinya dalam masyarakat. Sesuai dengan inti teori lapisan bahwa "istilah kelas tidak selalu mempunyai arti sama, walaupun pada hakekatnya mewujudkan sistem kedudukan-kedudukan yag pokok dalam masyarakat". Artinya setiap kedudukan diakui dan dan disadari dalam masyarakat bukan sebagai pembeda dalam lapisan masyarakat, tetapi digunakan sebagai acuan untuk menentukan profesi individu dalam kehidupan bermasyarakat yang harus dijalankan sebagai suatu kewajiban.

Perubahan dalam kehidupan sosial pasti terjadi dan hal ini berlangsung selama masih ada kehidupan di muka bumi ini. Peningkatan status sosial individu dalam masyarakat terjadi sesuai dengan profesi yang ditekuni, perubahan dan peningkatan kedudukan seseorang mutlak adanya. Salah satu pemahaman terhadap catur kasta/warna terutama mengenai bagaimanakah status sosial kemasyarakatan individu berdasarkan ajaran catur asrama. Problematik hidup cukup beragam dan komplek mengharuska individu hidup diatur oleh peraturan, norma dan kaidah yang mengingkarinya.

Kasta adalah sebuah karakter dari masyarakat yang membentuk diri dalam kelompok, susunan yang alami. Warna/kasta menggambarkan semangat karakteristik yang sintesis dalam pikiran Hindu dengan keyakinan terhadap kolaborasi dari ras dan kooperasi dari budaya, sistem kasta adalah hasil dari toleransi dan kepercayaan. Disisi lain warna/kasta secara rasial merupakan penekanan dari perbedaan yang pasti dalam kelompok manusia yang tidak mungkin dapat dihapus atau dimusnahkan oleh perubahan sosial. Catur asrama yakni brahmacarya, grehasta, wanaprasta dan sanyasin/biksuka asrama. Keempat tahapan/ jenjang kehidupan ajaran agama Hindu wajib dilaksanakan oleh umat Hindu, karena individu hidup bersama dalam masyarakat baik secara intern maupun secara ekstern. Ajaran ini menentukan terhormat atau tidaknya seorang individu dalam kedudukannya di masyarakat yang homogen dan multikultur yang berlandaskan nilai-nilai dan normanorma sebagai aturan hidup. 
Peralihan status sosial individu disesuaikan dengan profesi yang ditekuni dalam masyarakat berdasarkan ilmu pengetahuan, penghargaan berupa kehormatan dan kekuasaan. Lapisan dalam masyarakat menjadi penting karena akan menentukan kewajiban yang dijalankan individu. Profesi sebagai pendeta, sebagai aparat negara, sebagai penggerak perekonomian masyarakat dan sebagai petani merupakan profesi dalam lapisan masyarakat. Perubahan profesi dapat terjadi karena ilmu pengetahuan, pendewasaan berumah tangga, intropeksi diri dan menanggalkan semua kedudukan di dunia ini ke tahapan yang lebih komplek. Catur asrama memberi arah kedudukan individu dalam masyarakat.

\section{Simpulan}

Berdasarkan penjelasan di atas maka dapat disimpulkan bahwa setiap individu dalam masyarakat akan berubah apabila dilihat dari ajaran catur asrama, di mana ajaran ini akan memberi arah terhadap status atau kedudukan seseorang atau individu dalam lapisan masyarakat. Peralihan status sosial individu tentu disesuaikan dengan profesi yang ditekuni dalam masyarakat yang diperoleh dari penguasaan ilmu pengetahuan, penghargaan berupa kehormatan dan kekuasaan. Lapisan dalam masyarakat menjadi penting karena hal ini yang akan menentukan kewajiban yang dijalankan individu baik untuk diri sendiri maupun untuk orang lain, karena tidak semua profesi mampu dan dapat dilaksanakan oleh seseorang yang memiliki profesi berbeda. Sesuai dengan ajaran Hindu profesi tersebut yakni sebagai pendeta, sebagai aparat negara, sebagai penggerak perekonomian masyarakat dan sebagai petani. Perubahan profesi ini dalam masyarakat wajib dilalui dengan tahapan belajar atau menuntut ilmu pengetahuan, melalui pendewasaan berumah tangga, melalui intropeksi diri terhadap keberadaan kehidupan duniawi dan masa menanggalkan semua kedudukan di dunia ini ke tahapan yang lebih komplek yakni kedudukan atau status sosial sebagai maha guru yang mulia karena sudah tidak mengalami suku dan duka duniawi.

\section{Daftar Pustaka}

Karda, I Made dkk. 2007. Sistem Pendidikan Agama Hindu 
(Berdasarkan SK. Dikti No :

38/DIKTI/Kep/2002). Paramita.

Surabaya.

Mertha, I Nengah. 2009. Menggatang

Hidup di Jaman Kaliyuga. Widya

Dharma. Denpasar.

Richards, Glyn. 2004. Sumber

Hinduisme Modern (Tokoh-

Tokoh Besar Pembaharu Hindu).

Paramita. Surabaya.

Soekanto, Soerjono. 2009. Sosiologi

Suatu Pengantar. Rajawali

Press. Jakarta

Syarbaini Syahrial dan Rusdiyanta.

2009. Dasar-Dasar Sosilogi.

Graha Ilmu. Yogyakarta. 
